\title{
APPLIED OF STRATEGIES IN THE FIELDS OF POWER BY NOVELIST : HABIBURRAHMAN EL SHIRAZY
}

\author{
Dedi Pramono $^{1}$, Faruk ${ }^{2}$, Aprinus Salam ${ }^{3}$ \\ \{dedi.pramono@idlitera.uad.ac.id ${ }^{1}$, farukkhan@ugm.ac.id ${ }^{2}$, aprinus@ugm.ac.id ${ }^{3}$ \} \\ 1,2,3Program Studi Sastra Indonesia, Universitas Ahmad Dahlan, Jalan Kapas 9, Semaki Yogyakarta, \\ UGM Bulaksumur, UGM Bulaksumur, Indonesia
}

\begin{abstract}
This paper has an aim to explore the strategy of using economic, social, and cultural capital (education and religious knowledge) made cultural production and competition within the fields of power. This agent, who originated from an orthodox Islamic background, with all of his limitations (use the formal realism approach). This research uses literature method, documentation study, and field study. Novelist creativity emphasized the individual characteristics of main characters and depiction of the social and geographic background of Egypt and trajectory (meetings). To increase his popularity, relied on the strategies of reproduction (new works transformation novel to film) and capital reconversion (economic, social, and symbolic investment). Applied of strategies rises accumulation of economic capital was transformed to promote the articulation of social, cultural, and even symbolic capital within the field of power, and the Majelis Ulama Indonesia Pusat gave legitimacy as the head of Department for the Development of Islamic Culture.
\end{abstract}

Keywords: Strategies, Field of Power, Novelist, Habiburrahman El Shirazy

\section{Introduction}

Reader reception of Habiburrahman El Shirazy (HES) began when Ayat-Ayat Cinta (AAC)[1] was serialized in the national daily Republika from 8 April to 23 September 2004. Recognizing readers' interest, Republika published the story as a novel shortly after serialization ended. The first printing of 80 thousand copies sold out within 15 months (December 2004 - February 2006); as such, Ayat-Ayat Cinta sold an average of 5,300 copies per month, or 177 copies per day-a fantastic amount for novels in Indonesia (Pries)[2] . Readers' interest became increasingly intense following the release of a film adaptation, and soon 400,000 copies of the book had been sold.[3]

This success, however, did not guarantee the automatic recognition of HES as an auteur. To become known as an auteur, rather than a simple author, is not simple. Recognized litterateurs exert authoritative dominance, while aspiring writers undergo creative struggles to gain legitimacy from literary institutions that have themselves been legitimized. To face this dominance, HES' first strategy involved joining FLP (Forum Lingkar Pena), a literary group that emphasizes the creative production of literary works by young writers[4]. Members include young writers beginning their careers as well as authors whose legitimacy has been recognized [5], such as Helvy Tiana Rosa, Ahmadun Yosi Herfanda, Pipiet Senja, and Taufik Ismail. HES' joining FLP is congruent with the conceptual framework of Bourdieu[6]

\section{Field and Modals : Bourdieuan Theoretical Framework}

Bourdieu [7] argued that the literary field is built on a contestation of two hierarchal principles, namely the heteronomous principle, which is economically and politically dominant, and the autonomous principle, which is dominated by intellectuals with specific 'capital' and includes a level of economic independence. 
Capital is a form of social energy used by agents, which exists and is productive in the field in which agents produce and reproduce [8]. Bourdieu [9] was convinced that the most important types of capital in the field of cultural production are (1) symbolic capital, which refers to the accumulated prestige, fame, and consecration, and is constructed on a dialogue between knowledge (connaissance) and recognition (reconnaissance); (2) cultural capital, defined as an internal code through which agents seek empathy, appreciation, and competence in cultural relations. In Language and Symbolic Power [10], Bourdieu identified two other types of capital, namely economic capital and social capital. According to Bourdieu [11] economic capital is that related to means of production (machines, land, labor), material (income and possession), and money. Economic capital can be institutionalized through ownership, and can readily be used in other fields, given or inherited. In certain conditions, cultural and social capital can also be converted into capital with economic value, and thus be institutionalized.

Meanwhile, Bourdieu [12] defines social capital as all resources, both actual and potential, related to the possession of networks and institutional relations based in mutual recognition and knowledge. If someone is a member of a certain group, than he or she can be supported by collectively possessed capital. The extent of an agent's social capital depends on the intensity of the networks created, as well as the volume of economic, cultural, and social capital.

Bourdieu [13] divided literature into three genres, namely drama, novel, and poetry. Bourdieu began his comparison of the three from an economic perspective, relative stability, and hierarchy. From an economic perspective, the greatest position is occupied by drama, which produces the greatest economic profit from the bourgeoisie. Meanwhile, the lowest in the hierarchy is poetry, which according to Bourdieu produces zero profit for its producers. Between drama and poetry is the novel, which may provide significant (for naturalist novels) and exceptional (for popular novels) profit for their producers. However, within the field of cultural production, there exists an "inverted economy", where agents prioritize symbolic benefits over readership, sales, and copies printed (all beneficial for financial and social capital). As such, profit-oriented agents are the lowest in the hierarchy. In this, HES sought his own position through the cultural production of novels, particularly popular novels, which tend to be more pragmatic and emphasize readership. This was congruent with HES' desire to use his novels as a means of dakwah (Islamic teaching). As such, within Bourdieu's theoretical framework, HES could be considered oriented more towards obtaining economic, social, and cultural capital (no matter how limited) rather than symbolic capital.

Bourdieu [14] identifies three principles of literary legitimacy. First, the specific principle of legitimacy, namely the legitimacy given by producers (litterateurs) who are positioned as competitors. Second, the principle of legitimacy according to the tastes of the bourgeoisie, the dominant group, as indicated by salons and other groups such as academies, which have the authority to grant ethical dan aesthetic legitimacy in accordance with their tastes. Third, the principle of 'popular' legitimacy, the recognition granted by general consumers or the masses.

\section{Strategies Used by Habiburrahman El Shirazy within the Fields of Indonesia Power}

Bourdieu [9] argued that the most important types of capital in the field of cultural production are (1) symbolic capital, which refers to the accumulated prestige, fame, and consecration, and is constructed on a dialogue between knowledge (connaissance) and recognition (reconnaissance); (2) cultural capital, defined as an internal code through which agents seek empathy, appreciation, and competence in cultural relations. The second form of capital, cultural capital, is accumulated through a lengthy process, that involves families and groups (family education), educated members of society (broader education), and social institutions (institutional education). In this, HES has benefited from religious education, both informal (from orthodox family) and formal (from university in Egypt).

The success of HES as a novelist in the field of power in Indonesian was achieved through a variety of application strategies. From various thoughts Bourdieu [15] can be concluded into three strategies: creative, reproductive, and capital reconversion strategies 


\section{a. Creative Strategies}

The strategy applied by HES involved the application of formal realism, the transformation of the novel into film, and reproduction, none of which brought him specific symbolic capital (i.e. legitimacy as a litterateur). Most frequently interacted (trajectory) with 'legitimate' writers, including those active with Horison, Kompas, and Republika, as well as those involved in the academic community, the Dewan Kesenian Jakarta, and Forum Lingkar Pena; however, these interactions are limited primarily to greetings, discussion, and personal relations between community members and MUI officials. In his meetings with MUI officials, both at the regional and national level, HES has primarily focused on discussing cultural phenomena in contemporary society, as well as the potential for developing Islamic culture as well as his own position as the head of the Commission for the Development of Islamic Culture and Art at the MUI.

Another important thing in creative strategy is trajectory. Trajectory is understood as a breakthrough done by a writer in all environments that allows him to develop better. These developments can further enrich the ability of the author himself, also boost popularity. From the data obtained four field which are the object of the novelist's crossing: FLP (Forum Lingkar pena/author organsation), mosque activist, student organization, student organisastion, and muslimah organsation. The recapitulation of the trajectory by novelist is shown in the following table.

Table 1. Trajectory Pre and Post $A A C$ Published

\begin{tabular}{lllll}
\hline Subject/Official & Creative Writing & Religious & Literature Studies & Total \\
\hline FLP & 3 & - & - & 3 \\
Mosque Activist & 3 & 1 & & 4 \\
Student & 20 & 5 & 2 & 27 \\
$\begin{array}{l}\text { Organitation } \\
\begin{array}{l}\text { Muslimah } \\
\text { Organisation }\end{array}\end{array}$ & 2 & & 1 & 3 \\
Total & 28 & & 3 & 37 \\
\hline
\end{tabular}

From the data in the above table, it is illustrated that most of the crossings made by novelists are on the novelis position as the author $(76 \%)$, as the preacher $(16 \%)$, and as the scholars $(8 \%)$. The data shows HES has been recognized as a novelist rather than a preacher in the field of power.

In terms of legitimacy, novelist likewise did not make the calculations suggested by Bourdieu, who argued that agents in the field seek to accumulate cultural and symbolic capital, and gain specific legitimacy through their cultural products. Rather, as a literary producer, HES has sought to ensure that his 'works are read by as many people as possible, with the hope that they become stronger of faith (in their relations with God) and being polite in mu'amalah (in their relations with God's creations)'. The involvement of readers is a key component of dakwah literature.

\section{b. Reproductive Strategies}

The greatest amount of capital acquired was economic; HES became a billionaire through the success of his novel. Capital was also acquired in the form of social networks, particularly within the religious field. The acquisition of cultural and symbolic capital brought him the predicate "a soul-building novelist". This designation encourages the novelist to produce the next literary works such as Pudarnya Pesona Cleopatra (2005), Di Atas Sajadah Cinta (2006), Ketika Cinta Bertasbih (2007), Dalam Mihrab Cinta (2010), Dalam Mihrab Cinta, The Romance (010), Bumi Cinta (010), Cinta Suci Zahrana (2011), Ketika Cinta Berbuah Surga (2014), Api Tauhid (2014), and Ayat-ayat Cinta 2 (2015).

Reproductive strategy efforts are strengthened by the transformation strategy from novel to film. Based on the data obtained a picture that the transformation efforts have been made novelist since Ayatayat Cinta. The transformation activities are carried out between 1 to 3 years from the initial publication of the novel. In full, it can be seen in the data illustrated in table 2. 
Table 2. Transformation Novel to Film

\begin{tabular}{lllll}
\hline Title & Published & $\begin{array}{l}\text { Film } \\
\text { Production }\end{array}$ & Director & Scenario \\
\hline $\begin{array}{llll}\text { Ayat-Ayat Cinta } \\
\text { Ketika Cinta Bertasbih 1 }\end{array}$ & 2004 & 2008 & Hanung Bramantyo & Salman Aristo \\
Ketika Cinta Bertasbih 2 & 2007 & 2009 & Chaerul Umam & Imam Tantowi \\
Dalam Mihrab Cinta & 2010 & 2010 & Chaerul Umam & Imam Tantowi \\
Cinta Suci Zahrana & 2011 & 2011 & Habiburrahman El Shirazy & Adra P. Daniel \\
& & 2012 & Chaerul Umam & Misbach \\
Ayat-ayat Cinta 2 & 2015 & 2017 & Guntur Suhardjanto & Yusach Biran \\
& & & & Alin Sudio /Ifan \\
& & & & Ismail \\
\hline
\end{tabular}

\section{c. Capital Reconversion Strategies}

The economic capital collected by HES was used to establish the Yayasan Basmala Indonesia (Indonesian Basmala Foundation), which seeks to promote the creation of works (of any kind) and entrepreneurship (of any kind). The foundation's principle was that "if one loves one's religious community and nation: produce works; and if one loves Indonesia, develop an independent soul, an entrepreneurial soul, a soul that relies solely on he blessings of God the All-Wealthy and All-Loving" [16]. Economic capital was also used to establish a pesantren for works and entrepreneurship in Salatiga, which maintained through family foundation. HES hoped that, through this pesantren, a generation of young writers could be born and produce works of good quality while still maintaining Islamic values. Both of these foundations are administered by HES, his family, and his friend Pries GS. As such, HES used his economic capital to support these two foundations and accumulate other forms of capital, particularly social capital, or even cultural or symbolic capital. This means that, indirectly, HES rejected the literary practices and doxa produced by the consecrated people producing a (specific) legitimacy, i.e. that writers should seek to accumulate cultural (literary) and symbolic (the title litterateur) capital, rather than economic and social capital. Based on the data presentation and analysis, it can be concluded that the application of the novelist strategy is shown in table 3.

Table 3. Aplied of Novelist Strategies, Investement, and Acquisition of Capital Gains

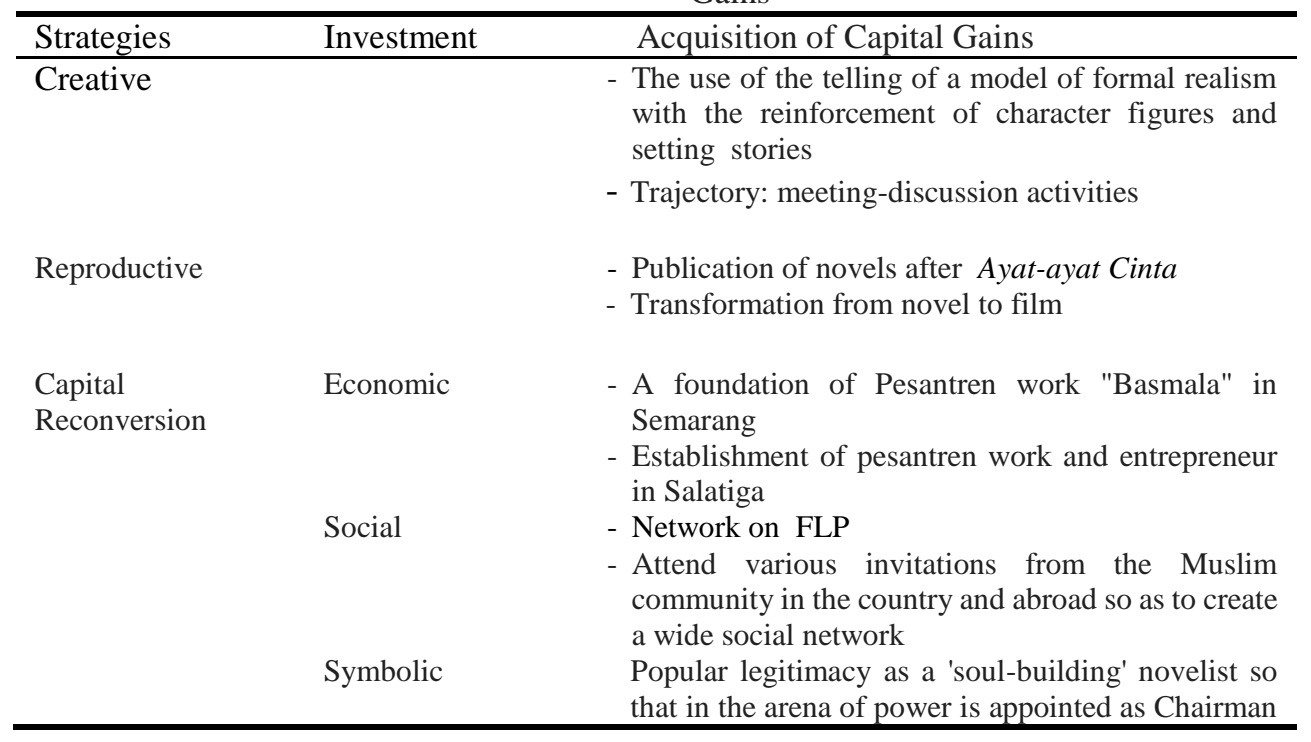




\section{Discussion}

HES' strategy of using his economic, social, and cultural capital (education and religious knowledge) made his cultural production and competition within the fields of power and literature. This agent, who originated from an orthodox Islamic background, with all of his limitations (i.e. his lack of recognition of literary rules and his inability to write literary works using the dominant formal realism approach). HES' creativity emphasized the individual characteristics of his main characters and his depiction of the social and geographic background of Egypt. The characters and Egyptian background were of considerable interest to Indonesian readers, who were then seeking examples of Muslims who obeyed Islamic law, were knowledgeable, and were polite in their religious thoughts and attitude. To increase his popularity, he relied on the strategies of trajectory (meetings/discussions and film adaptation) and reproduction (through new works and translations).

Bourdieu argues that literary producers will primarily seek specific legitimacy over bourgeois legitimacy or popular legitimacy. However, no such efforts were made by HES, who did not seek a revolution in the content and form of literature (which is frequently a criterion for gaining specific legitimacy). Agents such as HES have worked primarily to ensure that their 'works are read by as many people as possible, with the hope that they become stronger of faith (in their relations with God) and being polite in mu'amalah (in their relations with God's creations)'. This involvement of readers is a key component of dakwah literature.[17]

\section{Conclution}

In accumulation of economic capital, HES worked creatively. Economic profit was used as individual capital to establish the Yayasan Pesantren Mahasiswa Basmala in Semarang. As such, accumulation of economic capital was transformed to promote the articulation of social, cultural, and even symbolic capital within the field of power. For this, the Majelis Ulama Indonesia Pusat gave HES legitimacy within the religious field by making the head of its Department for the Development of Islamic Culture. 


\section{References}

[1] H. El Shirazy, Ayat-ayat Cinta. Jakarta: Republika-Basmala, 2004.

[2] G. Pries, "Ayat-ayat Cinta, Snobisme Membaca dan Legenda Sastra Santri," in Fenomena Ayat-ayat Cinta, Jakarta: Republika, 2007, p. 12.

[3] Awod, "Novel Populer Islami: Booming," Republika, Jakarta, p. 4, Aug-2008.

[4] H. T. Rosa, Matahari Tak Prnah sendiri, Kisah Seru Aktivis FLP. Depok: Lingkar Pena Publishing House, 2004.

[5] M. S. Mahayana, "Fenomena Forum Lingkar Pena," Jakarta, 2007.

[6] P. Bourdieu, "The Role Intellectual Today," A J. Soc. Polit. Theory, pp. 1-6, 2002.

[7] P. Bourdieu, The Field of Culture Production. Columbia: Colmbia University Press, 1993.

[8] R. Jenkis, Pierre Bourdieu. London: Routledge, 1992.

[9] P. Bourdieu, The Field of Cultural Production. Columbia: Colmbia University Press, 1993.

[10] P. Bourdieu, Language and Symbolic Power. Oxford: Polity Press, 1991.

[11] P. Bourdieu, "The Forms of Capital," in Handbook for Theory and Research for the Sociology and Education, New York: Greenwood Press, 1986, pp. 243-248.

[12] P. Bourdieu, "The Forms of Capital," in Handbook for Theory and Research for the Sociology and Education, New York: Greenwood Press, 1986, p. 249.

[13] P. Bourdieu, The Field of Cultural Production. Columbia: Colmbia University Press, 1993.

[14] P. Bourdieu, The Field of Cultural Production. Columbia: Colmbia University Press, 1993.

[15] P. Bourdieu, The Field of Cultural Production. Columbia: Colmbia University Press, 1993.

[16] H. El Shirazy, Ayat-ayat Cinta. Jakarta: Republika-Basmala, 2006.

[17] M. Sakai, "Preaching of Muslim Youth in Indonesia, the dakwah activities of Habiburrahman el-Shirazy," RIMA Rev. Indones. Malaysia Aff., vol. 46, p. 45, 2012. 